\title{
Zyskać na edukacji? Konsekwencje działań wolnorynkowych dla funkcjonowania edukacji przedszkolnej w Polsce
}

\section{STRESZCZENIE}

Celem tekstu jest zwrócenie uwagi na zmiany funkcjonowania oświaty w warunkach wolnorynkowych. Ze względu na szeroki obszar tego zagadnienia w artykule skoncentrowano się szczególnie na finansowaniu edukacji przedszkolnej, wskazując na jej powiązania z sytuacją polityczno-gospodarczą naszego kraju.

Poszukiwano odpowiedzi na pytania o konsekwencje działań wolnorynkowych dla edukacji przedszkolnej w wyniku oddawania zadań publicznych sektorowi prywatnemu, nastawionemu na zysk, oraz wprowadzania zasad działania sektora prywatnego do pracy instytucji publicznych. Poprzez zestawienie treści rozporządzeń MEN, dotyczących organizowania edukacji przedszkolnej, z danymi zawartymi w raportach GUS oraz „Diagnozy społecznej”, wskazano na konsekwencje niestabilności polityki oświatowej dla decyzji finansowych na szczeblu lokalnym, które mogą powodować narastanie kryzysu zaufania społecznego.

SŁOWA KLUCZOWE: wolny rynek edukacyjny, samorząd terytorialny, niepubliczne placówki oświatowe.

\section{Wprowadzenie}

Zderzenie humanistycznych idei z logiką rynku wywołuje dyskusje, których nie doświadczała oświata w Polsce przed okresem transformacji. Zmiany w funkcjonowaniu gospodarki wprowadziły zasady ekonomii kapitalistycznej w sfery do tej pory nierynkowe, takie jak edukacja, stając się czynnikiem zmiany warunków jej organizowania.

Celem artykułu jest podjęcie refleksji nad konsekwencjami działań wolnorynkowych wobszarze edukacji, na przykładzie funkcjonowania przedszkoli publicznych w Polsce. Wybranie wąskiego obszaru analiz związane jest zarówno z małą liczbą opracowań na ten temat (por. Karwowska-Struczyk, 2012; Potulicka, 2014), jak i koniecznością namysłu nad konsekwencjami stosowania zasad komercjalizacji w organizowaniu pierwszego szczebla systemu oświaty w Polsce, jakim jest edukacja przedszkolna. 
Podjęte rozważania mają na celu poszerzenie wiedzy, dotyczącej dwóch poziomów tego zagadnienia. Pierwszy dotyczy przejawów rynkowego podejścia do edukacji, do których należy stopniowa prywatyzacja placówek, a drugi, konsekwencji stosowania zasad komercjalizacji dla edukacji. Dążąc do wyjaśnienia obu kwestii odniosłam się do kluczowego dylematu, dotyczącego edukacji wolnorynkowej, jakim jest relacja pomiędzy indywidualnym zyskiem a dobrem społecznym.

Poprzez wskazanie podwójnego znaczenia pojęcia „zysk”, jako korzyści materialnej lub/oraz niematerialnej, zwracam uwagę, że wymiar korzyści może mieć znaczenie obiektywne, jako nadwyżka wpływów nad wydatkami, a także subiektywne, gdy rezultat działań jest odbierany jako podniesienie wartości podmiotowych. Wieloznaczność pojęcia ukazuje także jego synonim „zyskiwać”, który jest używany zarówno w znaczeniu przedmiotowym „zyskać na... (czymś, kimś)” lub podmiotowym „zyskać (coś)...”, na przykład doświadczenie, umiejętności, sławę (SŁownik Języka Polskiego, 2002, s. 891). Podejmuję zatem refleksję nad zmieniającym się znaczeniem zyskowności w odniesieniu do edukacji przedszkolnej, przywołując najpierw treści wybranych źródeł wtórnych, dotyczących jej organizowania, jak rozporządzenia MEN, raporty GUS 2013-2015 oraz Diagnoza SpoŁeczna (Czapiński, Panek, 2015), a następnie przystępuję do krytycznej analizy komercjalizacji placówek publicznych.

\section{Oddawanie zadań własnych samorządu w prywatne ręce}

Konsekwencje działania wolnego rynku dla wielu dziedzin życia społecznego są tematem licznych opracowań, jednak rzadko dotyczą one wczesnej edukacji. Eugenia Potulicka zwróciła uwagę na tendencję ogólnoświatową, dotyczącą marginalizowania tego szczebla oświatowego, pisząc:

wczesna edukacja pozostaje na peryferiach uwagi w niemal wszystkich systemach edukacji, co przejawia się w niedostatecznych zasobach i fragmentarycznym planowaniu (Potulicka, 2014, s. 15).

Dokonanie analizy konsekwencji działań wolnorynkowych dla funkcjonowania edukacji przedszkolnej w Polsce nie jest możliwe bez uwzględnienia kontekstu decyzji urzędowych, które przyczyniły się do komercjalizacji w tym obszarze usług społecznych.

Kontekst ten można opisać poprzez wskazanie kolejnych zarządzeń MEN, wśród których szczególnie istotne dla podjętego problemu są Ustawy z 1991, 2010 i 2013 roku. 
Pierwsza data wiąże się z przełomem ustrojowym oraz realizacją porozumień Okrągłego Stołu w zakresie edukacji, których efektem stała się Ustawa o systemie oświaty z 1991 r. Przebieg transformacji ustrojowej skomplikował realizację postulatu Solidarności, dotyczącego likwidacji dysproporcji między szkolnictwem w mieście i na wsi, na co zwrócił uwagę Bogusław Śliwerski (2009, s. 58), dokonując krytycznej analizy początków działania nowego systemu edukacji po roku 1990. Autor wykazał, że przejęcie organizowania i zarządzania przedszkolami przez gminy wprowadziło już wówczas wymiar ekonomiczny w myśleniu o edukacji.

Co prawda kształtująca się wówczas idea samorządności miała być przejawem demokratyzacji. Jednak, w przypadku przedszkoli, samorządy lokalne otrzymały zadanie do wykonania, które ograniczono centralnymi decyzjami MEN oraz o których finansową wykonalność nie zadbano. Do tego zagadnienia odniósł się B. Śliwerski (2015, s. 26) przywołując zapis Europejskiej Karty Samorządu Lokalnego, dotyczący koniecznej adekwatności deklarowanych przez społeczności lokalnych zasobów finansowych, do zakresu uprawnień przyznanych im przez państwo. Konsekwencją niedofinansowania gmin w zakresie usług społecznych stały się strategie, pozwalające stopniowo obniżać wydatki na edukację przedszkolną.

Początkowo polegały one na zamykaniu placówek, co prowadziło do zmniejszania się liczbę miejsc dla dzieci w wieku przedszkolnym. Próbą wyjścia z tego impasu stało się Rozporządzenie MEN z 2010 roku, dotyczące rozszerzenia sieci przedszkoli o inne formy wychowania przedszkolnego (punkty i zespoły przedszkolne), o krótkim wymiarze czasowym oferty edukacyjnej (minimum 3 godziny). Stworzono tym samym możliwość zastąpienia istniejącej wcześniej struktury przedszkoli publicznych różnorodnymi postaciami form quasi-przedszkolnych, prowadzonych przez osoby fizyczne oraz inne niż samorząd podmioty.

Obowiązywała już wówczas Ustawa o swobodzie działalności gospodarczej (od 2004 roku), która wprowadziła punkt „wychowanie przedszkolne” do ewidencji klasyfikacji działalności (PKD 85.10.Z), tworząc konstrukt „usługi edukacyjnej”. W konsekwencji tych rozporządzeń warunki organizowania edukacji przedszkolnej zaczęły podlegać mechanizmom popytu i podaży,

Początkowo określenie „usługi edukacyjne” dotyczyło różnych form działalności gospodarczej, zakładanych zgodnie z Ustawą z 2004 roku (Polska Klasyfikacja Działalności sekcja P, dział 85 Edukacja). W obecnym dyskursie ekonomicznym formuła „usługa edukacyjna” jest definiowana jako: „usługa profesjonalna, świadczona przez wysoko wykwalifikowany personel, posiadający odpowiednią wiedzę i praktykę w zakresie kierowania procesem zdobywania wiedzy, kształtowania osobowości i doprowadzania do określonej zmiany w umyśle klienta”. 
charakteryzujących zjawisko wolnego rynku. Właściciele niepublicznych placówek (potocznie określanych prywatnymi przedszkolami), stanowiących rodzaj mikroprzedsiębiorstw, stali się atrakcyjnymi partnerami gmin, odciążając budżety samorządów.

W 2013 roku ustawodawca zmienił artykuł 14 Ustawy o systemie oświaty ${ }^{2}$, umożliwiając gminom, w świetle prawa, wykonywać zadanie własne przez zamówienie usługi edukacyjnej u osób fizycznych lub prawnych (tzw. przedszkole publiczne niesamorządowe) w trakcie konkursów ofert. Jak można wyczytać w warunkach konkursowych, ogłaszanych na portalach urzędów gmin, celem konkursu jest realizacja zadania publicznego z zakresu wychowania przedszkolnego. Ponieważ Ustawa nie wskazuje na konieczność konsultacji społecznych w tym zakresie, mieszkańcy nie są powiadamiani o prywatyzacji placówek w gminie, dopóki nie stanie się ona faktem.

W tym miejscu warto się odnieść do tytułowej kategorii zyskowności na edukacji, aby wskazać na przesuwanie się jej znaczenia. Z jednej strony mamy do czynienia z obiektywnymi korzyściami materialnymi gmin, jak wpływy z dzierżaw budynków komunalnych osobom prywatnym czy oszczędności na remontach placówek przedszkolnych.

Jednak innym wymiarem zysku staje się obniżanie kosztów wynagrodzenia nauczycieli przedszkola, zatrudnianych przez właścicieli z pominięciem zapisów Karty nauczyciela, lub minimalizacja kosztów usługi przez zatrudnianie „tańszych” nauczycieli z niepełnymi lub niższymi kwalifikacjami (Sajdera, 2014).

Na wynagradzanie nauczycieli ma wpływ wysokość udzielanej dotacji, dlatego różnice zasobności gmin prowadzą do różnic w warunkach pracy nauczycieli. Gdy w systemie oświaty obok siebie funkcjonują zarówno publiczne, jak i niepubliczne przedszkola, istnieją znaczne rozbieżności w wynagrodzeniu, czasie pracy oraz uprawnieniach tej samej grupy zawodowej. Różnice związane są także z dostępem do ścieżek awansu i dokształcaniem się, gdyż przy 8- lub 9-godzinnym czasie pracy i niskim wynagrodzeniu stają się one nierealne bez wsparcia właściciela. Samorządy są jednak świadome, że w sytuacji braku zatrudnienia w ubogich gminach nauczyciel nie będzie miał innego wyboru, niż kontynuowanie pracy w niepublicznej placówce, przekształconej z przedszkola samorządowego (Kobylacki, Dutkiewicz, 2012, s. 60).

2 Najnowsza aktualizacja artykułu 14 Ustawy o systemie oświaty ma wejść w życie 01.09.2017 r., jednak trwają obecnie dalsze prace na zmianą Ustawy. Ostatnie informacje pochodzą z Dz. U. 2015, poz. 2156 oraz 2016, poz. 35, 64 i 195. 
W konsekwencji rosnącej liczby przedszkoli niesamorządowych w najbliższych latach może pogłębiać się segmentacja rynku pracy nauczycieli, powodując stopniowe ograniczanie ich przywilejów, wynikających z Karty nauczyciela.

\section{Zyskać na wskaźnikach „uprzedszkolnienia”}

Wykorzystanie przez samorządy lokalne mechanizmów rynkowych do sprawniejszego reorganizowania wychowania przedszkolnego jest popierane przez MEN, gdyż pozwala na realizację zaleceń Komisji Rady Unii Europejskiej, aby w 2018 roku wskaźnik uczęszczania dzieci do przedszkoli osiągnął poziom $92 \%$.

W dokumencie Komisji Europejskiej (2013) wskazano na pozytywne rezultaty zapewnienia przez Polskę stabilnego finansowania wysokiej jakości, dostępnej i przystępnej cenowo opieki nad dziećmi i edukacji przedszkolnej. Są one przykładem nadawania znaczenia kategorii zyskowności w rozumieniu subiektywnym, a więc zyskania „czegoś” poprzez wartościową edukację. Na przykład dostępność edukacji przedszkolnej, a także instytucji opieki dla dzieci przed 3. rokiem życia, skutkować może zmniejszaniem nierówności społecznych i marginalizacji. Zapewnienie opieki nad dziećmi wiąże się ze zwiększeniem aktywności zawodowej rodziców, przede wszystkim młodych kobiet. Także wydłużenie wieku emerytalnego kobiet stwarza konieczność ich pracy zawodowej, uniemożliwiającej pomoc w wychowaniu wnuków.

Instrumentem realizacji zaleceń RE w Polsce jest Krajowy Program Reform Europa 2020, który w dokumencie z dnia 25 kwietnia 2015 przedstawił sposoby ich realizacji (s. 80). Jednak zaplanowane od 1 września 2017 roku podniesienie „wskaźnika uprzedszkolnienia” nie wydaje się możliwe w związku z decyzjami nowych władz MEN. W związku z ponownym podwyższeniem wieku rozpoczynania obowiązku szkolnego, realizacja tego zadania będzie wymagała dalszego uzupełniania miejsc dla dzieci trzyletnich siecią placówek niepublicznych różnego rodzaju (punkty i zespoły przedszkolne). Wypowiedziała się już na ten temat Anna Zalewska, obecna Minister Edukacji Narodowej w wywiadzie dla radia Radia TOK FM"

W Ministerstwie Rozwoju rozmawiamy obecnie o przedszkolnych start-upach. Uruchomienie tego typu placówki - oprócz kwestii edukacyjnych - może być na przykład dobrym pomysłem na biznes dla małego przedsiębiorcy. Mamy też sporo fundacji czy spółek skarbu państwa, które mogłyby zainwestować w takie projekty.

3 http://wyborcza.pl/magazyn/1,151485,19889350,minister-anna-zalewska-mickiewicz-da-szkole.html. [data dostępu: 11.04.2016]. 


\section{Powszechna nierówność}

Jeszcze innym wskaźnikiem „uprzedszkolnienia” jest powszechny dostęp do edukacji. Jak zostało to już wcześniej wspomniane, jeden z postulatów Solidarności dotyczył likwidacji dysproporcji między szkolnictwem w mieście i na wsi zwłaszcza w zakresie upowszechniania wychowania przedszkolnego. Jednak, jak informują Janusz Czapiński i Tomasz Panek, autorzy raportu Diagnoza SpoŁeczna (2015), pomimo upływu lat nadal utrzymują się dysproporcje w liczbie korzystających z edukacji przedszkolnej, dotyczące klasy miejscowości zamieszkania. Widoczny jest szczególnie regres w małych miasteczkach poniżej 20 tys. mieszkańców, co zdaniem autorów raportu przekłada się na „wykluczenie matek z rynku pracy do momentu osiągnięcia przez dziecko wieku 5 lat [...] szczególnie niekorzystne dla kobiet zamieszkujących wsie" (Diagnoza SpoŁeczna, 2015, s. 98).

Lokalny rozkład uczęszczania dzieci do przedszkoli w roku 2014/2015 według GUS pokazuje dysproporcje między gminami, które z kolei pokrywają się ze wskaźnikami bezrobocia w tych rejonach. Szczególnie jest to widoczne w przypadku województwa warmińsko-mazurskiego (bezrobocie 17\%) i kujawsko-pomorskiego (bezrobocie $13,9 \%)^{4}$. Nie zmienił tych dysproporcji nawet zagwarantowany Ustawą pięciogodzinny czas bezpłatnego nauczania, wychowania i opieki w przedszkolach. Warto zauważyć, że konsekwencje tej oszczędnej oferty przedszkolnej ponoszą dzieci uboższe, których rodziców nie stać nawet na niewielkie dopłaty, zatem przebywają w przedszkolu w mniejszym wymiarze czasu, niż bardziej zamożni rówieśnicy. Gminy zarabiają więcej na przedszkolach publicznych w dużych miastach, ponieważ więcej dzieci pracujących rodziców zostaje dłużej w placówce, niż przez bezpłatnych pięć godzin, co wiąże się z opłatami za pozostałe godziny oraz posiłki. Rodzice majętni znajdują także rozwiązanie dla zajęć dodatkowych, które aranżują odpłatnie dla swoich dzieci na terenie przedszkoli. Jednocześnie, jak zauważa Anna Ciepielewska-Kowalik (2014, s. 73), rozwija się „outsourcing” usług edukacyjnych poprzez współpracę z firmami zewnętrznymi, oferującymi pielęgnację ogrodów, dowóz, catering, aranżację sal itp.

Jeszcze innym wymiarem tego problemu jest nierówny dostęp do edukacji przedszkolnej, spowodowany odmiennymi kryteriami naboru w gminach. Zdaniem Marii Theiss (2015) jest to narzucanie obywatelom odmiennych kryteriów lokalnych przy równych prawach do korzystania z usług (także edukacyjnych). Podstawowym warunkiem jest opłacanie podatków w miej-

4 Liczba bezrobotnych zarejestrowanych oraz stopa bezrobocia według województw, podregionów i powiatów. Stan w końcu stycznia 2016 r. 
scu zamieszkania, a pozostałe różnice dotyczą trzech aspektów: dostępności usługi, możliwości kontynuowania uczęszczania do placówki w kolejnych latach oraz preferencji przy zapisie dziecka. Autorka zauważa również, że „rola tych praktyk jest tym wyższa, im niższy stopień skolaryzacji przedszkolnej w gminie” (Theiss, 2015, s. 33). Ponieważ świadczenie usług edukacyjnych nie ma charakteru prawa podmiotowego, z samego faktu nałożenia na gminę zadań własnych, nie wynika możliwość ich egzekwowania przez członków wspólnoty lokalnej.

Konsekwencją nierównomiernego rozkładu wydatków gmin na przedszkola, w porównaniu ze szkołami podstawowymi czy gimnazjami ${ }^{5}$, są powiększające się nierówności w dostępie do dobrej jakościowo edukacji. Wobec stawiania wymogu ekonomiczności placówkom oświatowym (koszty utrzymania nie powinny znacząco przekraczać subwencji oświatowej lub dotacji celowej), zasady ich funkcjonowania stają się podporządkowane zarządzaniu rynkowemu, nastawionemu na maksymalizację efektów przy minimalizacji kosztów.

\section{Konkluzje}

Niejednoznaczne rozumienie zysku edukacyjnego jest obserwowane w wielu krajach świata, na co wielokrotnie zwracała uwagę Potulicka (2014). Porównując sytuację edukacji przedszkolnej w Polsce na tle innych krajów, warto skupiać się nie tylko na liczeniu miejsc w placówkach, ale wyciągać wnioski z dostrzeganych przez badaczy negatywnych konsekwencji rynkowego podejścia. Ilustracją takich przemyśleń jest publikacja, w której Gunilla Dahlberg, Peter Moss i Alana Pence (2013) krytykują sytuację placówek wczesnej edukacji w krajach zachodnich:

Nic w naszej ponowoczesnej perspektywie nie usprawiedliwia złego finansowania i administracyjnego rozdrobnienia instytucji dla małych dzieci, ani też przerażających nierówności społecznych i ekonomicznych między dziećmi i ich rodzinami, na których pojawienie się w świecie angloamerykańskim pozwolono w ostatnich latach (Dahlberg, Moss, Pence, 2013, s. 59).

Podejmując refleksję nad przesuwaniem znaczenia „zyskowności” w odniesieniu do edukacji wieku przedszkolnego, należy zdawać sobie sprawę $z$ dużej dynamiki zmian decyzji oświatowych w Polsce. Wpływa na nie zarówno demografia, ustawy tworzone przez kolejnych ministrów MEN (np.

Według GUS (s. 59) w roku 2014/2015 z budżetu samorządów terytorialnych na edukację przedszkolną przeznaczane było 4,8 mld, na szkoły podstawowe 14,4 mld. 
Ustawa o systemie oświaty była nowelizowana ponad 70 razy) oraz sytuacja polityczna.

Na podstawie przedstawionych w artykule rozważań można zauważyć, że gdy edukacja zaczyna być traktowana jak usługa i/lub oferta, staje się przedmiotem handlu i obiektem zysku. W konsekwencji podlega mechanizmom wyznaczanym przez rynek: popytu i podaży, konkurencyjności, większej wydajności przy oszczędności środków, na co zwrócił uwagę Gareth Morgan (2005), badacz kultury organizacji. Autor podaje przykłady na to, jak pozornie subtelne oddziaływanie transmitowanych społecznie systemów wartości (na przykład wolnorynkowych) może spowodować stopniową dewaluację wartości uniwersalnych. Jeśli działanie organizacji jest silnie związane z systemem finansowania, wówczas jej członkowie stanowią swoiste „ośrodki zysku generujące koszty i przychody” (Morgan, 2005, s. 150). Symbolem nosicieli nowych wartości czyni księgowych, których nazywa „konstruktorami rzeczywistości”, gdyż, jego zdaniem, potrafią umiejętnie zaszczepiać przekonanie o priorytecie zysku finansowego nad innymi działaniami organizacji.

Jednocześnie pojawia się niebezpieczeństwo odwróconej reguły rynkowej, o której Zbigniew Kwieciński wspominał już na konferencji w Olecku w 1996 roku. Dotyczy ona sytuacji, w której zamiast „«dobrego towaru za dobrą cenę» [...] sprzedają "zły towar za dobrą cenę», podczas gdy dobry towar jest... bezpłatny" (Kwieciński, 1997, s. 35). Autor odnosił wówczas te słowa do obecności gry rynkowej w funkcjonowaniu szkół wyższych, zwracając uwagę, że w jej trakcie zatraca się najważniejszy „składnik podaży - kompetencje akademickie".

Poprzez odniesienie się do tej wypowiedzi dokonuję podsumowującej refleksji nad znaczeniem pojęcia „zysk” w świetle przeprowadzonej analizy, wskazując na niebezpieczeństwo „zatracenia najważniejszego składnika podaży", jakim jest jakość edukacji przedszkolnej. Jak stwierdza Philip Zimbardo (2012), obok licznych badań, wskazujących pozytywne skutki edukacyjne instytucji edukacyjnych, zwracają uwagę także wyniki badań, które pokazują negatywne skutki oddziaływania opieki niskiej jakości na osobowość dziecka. Szczególnie niekorzystne efekty rozwojowe (agresja, przygnębienie, nieprzystosowanie społeczne) daje oddziaływanie dwóch czynników - niskiej jakości opieki instytucjonalnej (m.in. duża liczba dzieci na jednego opiekuna) przy jednoczesnym stresie rodzinnym, dotyczącym dzieci z rodzin niewydolnych wychowawczo (Zimbardo, 2012, s. 210).

Zatraceniu jakości edukacji przedszkolnej sprzyjać może dążenie do zysku: 
- na „czymś” : na utrzymywaniu edukacji przedszkolnej z finansów obywateli, którzy dotują swoimi podatkami placówki publiczne, a w przypadku wielu rodziców, szczególnie dzieci młodszych, ponoszą dodatkowe opłaty za placówki niepubliczne.

- na „kimś”: na dziecku, które „kosztuje” państwo tylko przez 5 godzin dziennie, na nauczycielu, który nie ma szans na pracę w placówce samorządowej, a tym samym nie ma szans na przywileje Karty nauczyciela, chociaż ma takie samo wykształcenie, jak kolega z innej gminy.

Zyskowność przyjmuje znaczenie wymiernych korzyści dla zarządzających oświatą oraz jej oferentów. Dążenie do „uprzedszkolnienia” wydaje się być najważniejsze dla władz oświatowych, ponieważ świadczy o aktywnym realizowaniu zaleceń unijnych, a zatem daje dostęp do środków finansowych na ten cel. Uzyskanie korzyści w tym zakresie mierzone jest liczbą miejsc dla dzieci $\mathrm{w}$ wieku przedszkolnym, ma zatem wymiar materialny. Jednocześnie tworzone są raporty, wykazujące wymierne korzyści wczesnej edukacji z punktu widzenia ekonomii (Brzezińska, Czub, Czub, 2012, s. 27), wśród których dominują neoliberalne przesłanki:

większą samodzielność w zaspokajaniu potrzeb i lepsze samopoczucie, warunkują lepsze efekty kształcenia na wszystkich poziomach edukacji oraz dają większe szanse odniesienia sukcesu na rynku pracy (znalezienie i utrzymanie pracy) oraz sukcesu życiowego.

Takie raporty powstają od wielu lat w państwach zachodnich, a szczególnie w USA, stając się wręcz, jak stwierdza E. Potulicka, trendem w myśleniu o wczesnej edukacji w charakterze policzalnej "dywidendy” (Potulicka 2014, S. 10).

Konsekwencje decyzji centralnych, dotyczących finansowania oświaty, ponoszą także same gminy, ponieważ nieprzejrzystość reguł „samorządnego" zaspokajania potrzeb edukacyjnych mieszkańców regionu prowadzi do dystansu oraz braku wiarygodności podejmowanych decyzji. Ten ostatni warunek, jak pisze Russell Hardin (2008, s. 556), jest kluczowy dla obdarzania zaufaniem i woli współpracy w społeczeństwie, a więc powinien być traktowany jako źródło podmiotowego zysku, podnoszącego wartość relacji w środowisku lokalnym.

Zyskowność edukacji polega przede wszystkim na jej wymiarze podmiotowym, a przez to trudnym do finansowego oszacowania. Jeśli klientem oferty edukacyjnej jest dziecko, to nie tylko nie jest ono w stanie dokonać wyboru „towaru”, jaki chce zyskać, lecz nawet gdy go otrzymuje, nie dostrzega jego wartości. Może ją określić dopiero z perspektywy lat. Przegrywa jako kon- 
sument, ponieważ nie potrafi określić, jakie potrzeby ma zrealizować placówka (oferent usługi), do której zapisali go rodzice. Tym większa musi być odpowiedzialność władz oświatowych za jakość edukacji, która nie powinna być ograniczana przez aktualną koniunkturę gospodarczą, bieżące potrzeby finansowe gmin czy sytuację polityczną państwa, ale rozumiana jako niezbywalne prawo człowieka w okresie dzieciństwa.

\section{BIBLIOGRAFIA}

Brzezińska, A. I., Czub, M., Czub T. (2012). Krótko- i długofalowe korzyści z wczesnej opieki nad dzieckiem i edukacji. Polityka Społeczna, nr 1 tematyczny.

Ciepielewska-Kowalik, A. (2014). Rola sektora publicznego oraz prywatnego (for i non-profit) w zmniejszaniu różnic w edukacji przedszkolnej w Polsce AD 2013. Zmodyfikowany model mieszany czy prywatyzacja usług przedszkolnych? Problemy Wczesnej Edukacji, nr 26, s. $64-76$.

Dahlberg G., Moss P., Pence A. (2013). Poza dyskursem jakości w instytucjach wczesnej edukacji i opieki. Jezzyki oceny. Wrocław: Wydawnictwo Naukowe DSW.

Hardin, R. (2008). Zaufanie i społeczeństwo. W: P. Sztompka, M. Bogunia-Borowska (red.), Socjologia codzienności. Kraków: Wydawnictwo Znak.

Karwowska-Struczyk, M. (2012). Edukacja przedszkolna. W poszukiwaniu nowych rozwiązań. Warszawa: Wydawnictwo Uniwersytetu Warszawskiego.

Kobylacki, A., Dutkiewicz, T. (2012). Monitorowanie przedszkoli, prowadzonych przez inny niż samorząd organ prowadzący, w gminie Murowana Goślina. W: A. Levitas (red.), Innowacyjne przykłady zarządzania i finansowania oświaty przez samorządy. Baza dobrych praktyk. Warszawa: ORE.

Kwieciński, Z. (1997). Rynek edukacyjny a demokracja: sprzeczne wyzwania. W: A. Karpińska (red.), Szkolnictwo niepaństwowe. Partnerstwo czy konkurencja? Mazurska Wszechnica Nauczycielska, Olecko.

Morgan, G. (2005). Obrazy organizacji. Warszawa: Wydawnictwo Naukowe PWN.

Potulicka, E. (2014). Rynkowy model wczesnej edukacji a stanowisko profesjonalistów - perspektywa globalna. Problemy Wczesnej Edukacji, nr 26, s. 7-24.

Sajdera, J. (2014). Wolny rynek w edukacji przedszkolnej, czyli biznes z dzieckiem w tle. W: D. Klus-Stańska (red.), (Anty)edukacja wczesnoszkolna. Kraków, Impuls.

Szymczak M. (red.). (2002). Słownik Języka Polskiego. (T. 3). Warszawa: Wydawnictwo Naukowe PWN.

Śliwerski, B. (2009). Problemy współczesnej edukacji. Dekonstrukcja polityki oświatowej III RP. Kraków: Wydawnictwa Akademickie i Profesjonalne.

Śliwerski, B. (2015). O konieczności powrotu do subsydiarnej roli państwa w publicznej edukacji szkolnej dzieci i młodzieży. Pedagogika Społeczna, nr 3, s. 17-51.

Theiss, M. (2015). Konstruując obywatela gminy - polityka dostępu do usług przedszkolnych. Polityka Społeczna, nr 1, s. 30-35.

Zimbardo, P., Johnson, R., McCann, V. (2012). Psychologia. Kluczowe koncepcje. Podstawy psychologii. Warszawa: Wydawnictwo Naukowe PWN.

\section{DOKUMENTY ŹRÓDŁOWE}

Czapiński, J., Panek, T. (red.) (2015). Diagnoza społeczna. Warunki i jakość życia Polaków. Warszawa: Rada Monitoringu Społecznego. Pozyskano z: www.diagnoza.com, [data dostępu 18.03.2016]. 
Główny Urząd Statystyczny (2015). Liczba bezrobotnych zarejestrowanych oraz stopa bezrobocia wedlug województw, podregionów i powiatów. Stan w końcu stycznia 2016. Pozyskano z: http://stat.gov.pl/obszary-tematyczne/rynek-pracy/bezrobocie-rejestrowane/liczba-bez-robotnych-zarejestrowanych-oraz-stopa-bezrobocia-wedlug-wojewodztw-podregionow-i-powiatow-stan-w-koncu-stycznia-2016,2,41.html, [data dostępu 18.03.2016].

Główny Urząd Statystyczny (2015). Oświata i wychowanie w roku szkolnym 2014/2015. Pozyskano z: http://stat.gov.pl/obszary-tematyczne/edukacja/edukacja/oswiata-i-wychowanie-w-roku-szkolnym-20142015,1,9.html, [data dostępu 15.03.2016].

Komisja Europejska (2013). Zalecenie Komisji z dnia 20 lutego 2013 r. Inwestowanie w dzieci: przerwanie cyklu marginalizacji (2013/112/UE). Dziennik Urzędowy Unii Europejskiej. Pozyskano z: http://eur-lex.europa.eu/legal-content/PL/TXT/PDF/?uri= CELEX:32013Ho112 \&qid=1458257993551\&from=PL, [data dostępu 18.03.2016].

Krajowy Program Reform Europa 2020. Aktualizacja 2015/2016. Przyjęty przez Radę Ministrów 28 kwietnia 2015 r. Pozyskano z: http://www.mg.gov.pl/files/upload/8413/KPR_2015-2016_ w_ost_PL.pdf, [data dostępu 18.03.2016].

Rozporządzenie Ministra Edukacji Narodowej z dnia 31 sierpnia 2010 r. w sprawie rodzajów innych form wychowania przedszkolnego, warunków tworzenia i organizowania tych form oraz sposobu ich działania. (Dz. U. 2010, nr 161, poz. 1080).

Ustawa $z$ dnia 13 czerwca 2013 r. o zmianie ustawy o systemie oświaty oraz niektórych innych ustaw (Dz. U. 2013, poz. 827).

Ustawa z dnia 7 września 1991 r. o systemie oświaty (Dz. U. 1991, nr 95, poz. 425).

\section{ABSTRACT}

\section{Benefit from education.}

Consequences of the free market for pre-school education in Poland

The purpose of the article is to draw attention to the changes in the functioning of education in free market conditions. Due to the broad area of issues, the author focuses on the financing of preschool education, which is in a special way connected with the political and economic situation of our country.

The author is looking for answers to the question concerning the consequences of the free-market environment for pre-school education resulting from the transfer of public tasks to the private for-profit sector and the introduction of the principles of the private sector to the work of public institutions.

The author compares the content of the Ministry of Education's regulations concerning the organization of pre-school education, with the information contained in the CSO and Social Diagnosis reports. In this way, the author points out the consequences of the instability of educational policy for financial decisions at the local level, which can lead to the growth of social trust crisis.

KEY WORDS: free market in education, local government, profit-making kindergartens. 